\title{
EVALUATION OF STRUCTURAL DESIGN OF ULTRA LARGE CONTAINER VESSEL
}

\author{
Nikola Vladimir, Šime Malenica, Ivo Senjanović, Jérôme De Lauzon, \\ Hong-Il Im, Dae-Seung Cho
}

\begin{abstract}
Summary
The trend in modern sea transportation is building of ever larger container vessels, which require application of different numerical tools according to the relevant methodologies, in order to achieve their reliable structural design. The aim of this paper is to review direct strength assessment procedure based on long-term hydro-structure calculations including whipping and springing. As illustrative example, ultra large container ship with a capacity of $19000 \mathrm{TEU}$ is selected and her structural design is evaluated both for fatigue and extreme response, respectively. Mathematical model is based on coupling of the 3D potential flow hydrodynamic model with the 3D FEM structural model. The general hydro-structure code HOMER, developed in Classification Society Bureau Veritas (BV) is used. Stress RAOs of selected structural details are obtained for full scatted diagram by the top-down procedure, and further used to assess their fatigue lives. Linear long term analysis is performed to define most contributing sea state to the vertical bending moment (VMB). Whipping response is computed on so called increased design sea state in time domain. Ultimate bending capacity was determined by nonlinear finite element analysis. Finally, extreme VBM is determined, and ultimate strength check according to the BV Rule Note NR583 was done.
\end{abstract}

Keywords: container ship; direct calculations; hydroelasticity; fatigue; extreme response; frequency domain; time domain.

\section{INTRODUCTION}

Specific characteristic of Ultra Large Container Ships (ULCS), compared to the other ship types, is that they are more likely to experience the hydroelastic type of structural response called springing and whipping $[1,2,3,4,5]$. That is mainly caused by their large dimensions leading to higher structure flexibility, relatively high operational speed and large bow flare [1]. Namely, nowadays ultra large container ship with 
a capacity of 20,000 TEU and length about $400 \mathrm{~m}$ are regularly being built. The Rules of classification societies, developed on the basis of long-term experience, are not directly applicable to ULCSs, and therefore direct calculations are necessary for their safe and rational design $[6,7,8]$. In this context some classification societies have developed guidelines (rule notes) for inclusion of hydroleastic effects, i.e. springing and whipping into the overall design procedure. Moreover, for that purpose there are several hydrostructure software available around the world, mainly relying on the same theoretical assumptions, but having incorporated different numerical procedures. Such tools are mostly based on the application of the 3D potential flow theoretical models for fluid flow coupled with the 3D FEM structural models [6,7,8].

This paper illustrates application of direct calculations to ship structural design evaluation, where selected results of hydroelastic analysis of 19000 TEU container ship designed by South Korean shipyard Hyundai Heavy Industries (HHI) are used. Fatigue assessment of several structural details was done, taking into account effect of linear springing. Also, ship ultimate capacity is calculated and compared with the relevant loading, that was determined taking into account slamming effects.

\section{METHODOLOGY DESCRIPTION AND OUTLINE OF THE MATHEMATICAL FORMULATION}

From methodology point of view, Bureau Veritas Rule Note NR583 is applied [9]. Generally, it deals with the part of structural analysis which aims at performing ultimate strength and fatigue assessment based on direct hydro-structure calculations including whipping and springing response. Application of BV Rule Note 583 includes:

- recommendations for springing and whipping assessment,

- methodology for long-term direct hydro-structure calculations including springing and whipping response,

- definition of service features and class notations WhiSp.

Additional service features or additional class notation WhiSp are defined as follows:

- WhiSp1 notation covers the effect of linear springing in the fatigue damage assessment, but whipping is considered neither for fatigue nor for ultimate strength,

- WhiSp2 notation corresponds to WhiSp1 notation with additional whipping computation for ultimate strength assessment,

- WhiSp3 notation corresponds to WhiSp2 notation with additional whipping computation for fatigue assessment.

In order to cover all types of hydro-structural interactions inherent to ships and offshore structures described in [9], the numerical software HOMER is developed in BV Research Department for the direct transfer of the hydrodynamic loads from the general seakeeping code to a structural FE model. Within the investigation presented in this pa- 
per, HOMER is used with Hydrostar, [10], as the hydrodynamic solver, and NASTRAN, [11], as the structural solver.

Although the assessment of the example ship was performed at all WhiSp1, 2 and 3 levels, respectively, (please, see [7]) here the results for WhiSp1 and 2 are presented only, due to reason of simplicity. It is also to be mentioned that for the time being, WhiSp3 class notation is only optional.

Fatigue assessment of selected structural details is performed according to the flowchart presented in Figure 1. Letters $\mathrm{H}$ and $\mathrm{S}$ in Figure 1 represent hydrodynamic loading and structural response, respectively. As shown in [3,7], hydrodynamic loading can be linear, weakly nonlinear and impulsive nonlinear, while structural response can be considered as the static or dynamic.

For the fatigue life calculation, very local stress concentrations are needed, and generally they can be calculated by refining the global coarse mesh or using the so called top-down approach. The former approach seems to be impractical leading to excessive number of finite elements, and therefore here, the latter one is used, which implies solving the global coarse mesh FEM problem at first, and applying the coarse mesh displacements at the boundaries of the local fine mesh later [12].

Within WhiSp1, fatigue analysis presented in this paper is carried out for a single loading condition, selected so as to maximise the still water bending moment in hogging. The sea states are modelled by Pierson-Moskowitz spectrum and "cos $n$ " spreading function, with $n=2$. Worldwide scatter diagram is used. The ship speed is taken to be as $60 \%$ of the ship design speed in all sea states, while values of the wave heading angle are considered uniformly distributed from $0^{\circ}$ to $350^{\circ}$ with step of $10.0^{\circ}$.

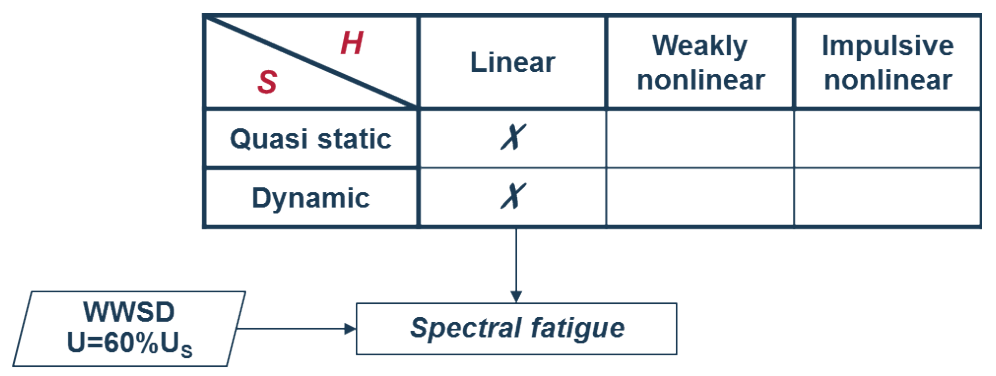

Fig. 1. Calculation procedure for spectral fatigue assessment with effect of linear springing [7].

SI. 1. Proračunski postupak spektralne procjene zamora s utjecajem linearnog pruženja [7].

Linear hydroelastic analysis performed here is based on the mode superposition method [13]. Within the modal approach, total displacement of a ship is expressed through a series of modal displacements: 


$$
\boldsymbol{H}(x, t)=\sum_{i=1}^{N} \xi_{i}(t) \boldsymbol{h}^{i}(x),
$$

where $\boldsymbol{H}(x, t)$ represents vector of total displacement of one point, $\boldsymbol{h}^{i}(x)$ is vector of modal displacement (mode shape), $\zeta_{i}(t)$ is modal amplitude, and $N$ represents the total number of modes. Generally, the procedure is very similar to rigid body analysis described in [3] except that the number of degrees of freedom is extended from 6 to 6 plus a certain number of elastic modes. The used modal approach implies the definition of supplementary radiation potentials with the following body boundary condition:

$$
\frac{\partial \varphi_{R j}}{\partial n}=\boldsymbol{h}^{j} \boldsymbol{n}
$$

where $\boldsymbol{n}$ is unit normal vector. After solving the different boundary value problems for the potentials, the corresponding forces are calculated and the matrix motion equation is written

$$
\left\{-\omega^{2}(\mathbf{m}+\mathbf{A})-i \omega(\mathbf{B}+\mathbf{b})+(\mathbf{k}+\mathbf{C})\right\} \xi=\mathbf{F}^{D I},
$$

where $\mathbf{m}$ is matrix of the modal structural mass, $\mathbf{b}$ is matrix of the structural damping, $\mathbf{k}$ is matrix of the structural stiffness, $\mathbf{A}$ is the hydrodynamic added mass, $\mathbf{B}$ is the hydrodynamic damping matrix, $\mathbf{C}$ is the hydrostatic restoring stiffness matrix, and $\mathbf{F}^{D I}$ is the modal hydrodynamic excitation vector. Once the modal amplitude vector $\xi$ has been calculated, the total stresses can be obtained, at least theoretically, by summing the individual modal contributions and one can formally write, [3]:

$$
\sum(x, \omega)=\sum_{i=1}^{N} \xi_{i}(\omega) \sigma^{i}(x)
$$

where $\Sigma(x, \omega)$ is the total stress and $\sigma^{i}(x)$ is the spatial distribution of modal stresses.

In order to practically take into account hydroelastic effects on the structural response, dynamic analysis computational scheme is applied, starting with modal analysis in dry condition [9]. Once the dry modes are obtained, the modal displacements are transferred from the structural model to the hydrodynamic one, and corresponding hydrodynamic problem is formulated. After that, fully coupled dynamic equation is solved, giving the modal amplitudes.

As mentioned above WhiSp2 calculation implies ultimate strength assessment with additional whipping computation [9]. The procedure is illustrated in Figure 2. At first, it is necessary to determine the linear long term value of vertical bending moment (VBM) and most contributing sea states to that value, by spectral analysis. After that, design sea states, for which time domain simulation are needed, should be determined. Then time domain simulations are run on design sea states, and statistical analysis of time signals is performed to obtain the non-linear value of VBM. According to [9], it is to be checked 
that the hull girder ultimate bending capacity at any cross-section is in compliance with the following formula:

$$
M \leq \frac{M_{U}}{\gamma_{R}},
$$

where $M_{u}$ represents ultimate bending capacity of hull transverse section, $M$ is computed extreme vertical bending moment and $\gamma_{R}$ is partial safety factor taken equal to 1.1.

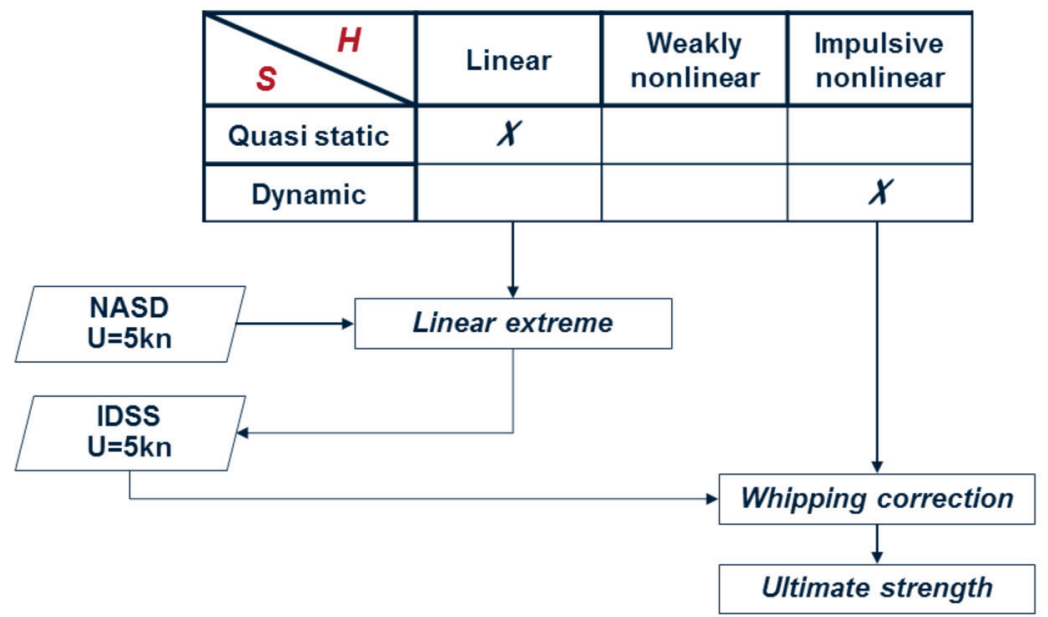

Fig. 2. Calculation procedure for ultimate strength evaluation [7].

SI. 2. Proračunski postupak za ocjenu granične čvrstoće [7].

\section{SHIP PARTICULARS AND CALCULATION MODELS}

The main particulars of the analysed 19000 TEU container ship are presented in Table 1.

Table 1. Main particulars of the considered container ship

Tablica 1. Glavne značajke analiziranog kontejnerskog broda

\begin{tabular}{|l|l|}
\hline Length over all, $L_{O A}[\mathrm{~m}]$ & 400 \\
\hline Length between perpendiculars, $L_{P P}[\mathrm{~m}]$ & 383 \\
\hline Breadth, $B[\mathrm{~m}]$ & 58.6 \\
\hline Depth, $H[\mathrm{~m}]$ & 30.5 \\
\hline Design draught, $T_{d}[\mathrm{~m}]$ & 14.5 \\
\hline Scantling draught, $T_{s}[\mathrm{~m}]$ & 16.0 \\
\hline Displacement at full load, $\Delta_{F}[\mathrm{t}]$ & 212913 \\
\hline Service speed, $v_{s}[\mathrm{kn}]$ & 23.0 \\
\hline
\end{tabular}


The global FE model with indicated positions of fine mesh models for fatigue life assessment is presented in Figure 3. In total 14 structural details of interest are selected. Beside both FE global and local (fine mesh) models of a ship structure, applied procedure and used numerical code also require generation of the so called integration mesh and hydrodynamic mesh, respectively, Figure 4, [14]. The former is extracted directly

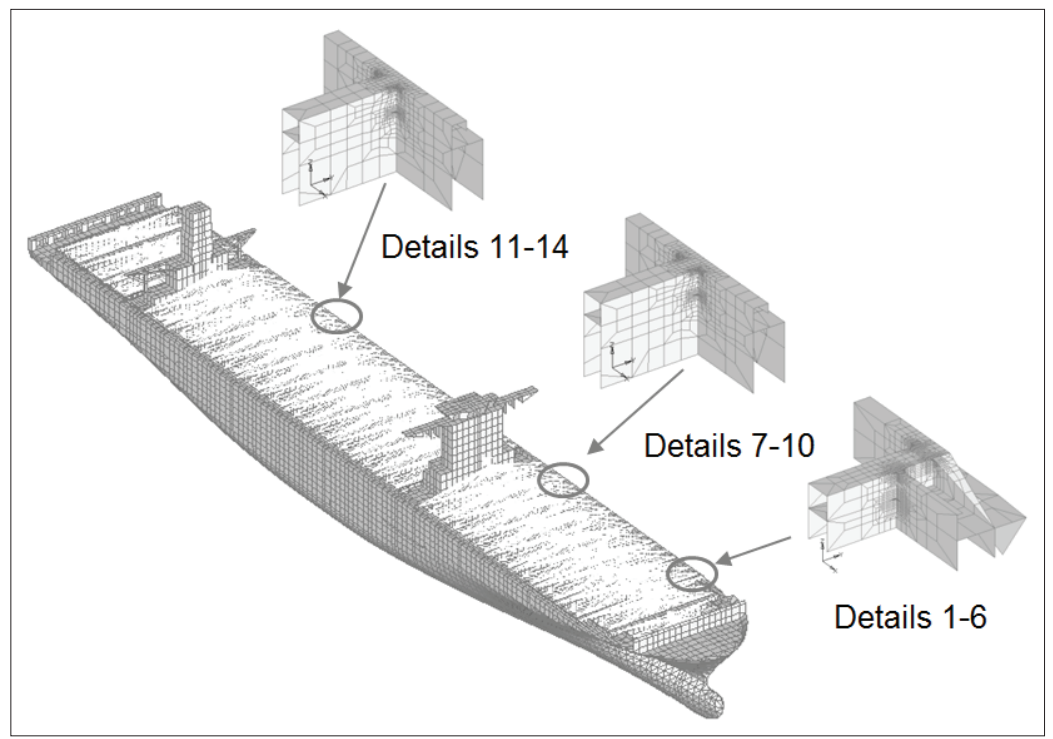

Fig. 3. Finite element model of the analysed ship with local fine mesh models and their positions along the ship.

SI. 3. Model konačnih elemenata analiziranog broda s lokalnim modelima fine mreže i njihovim pozicijama uzduž broda.

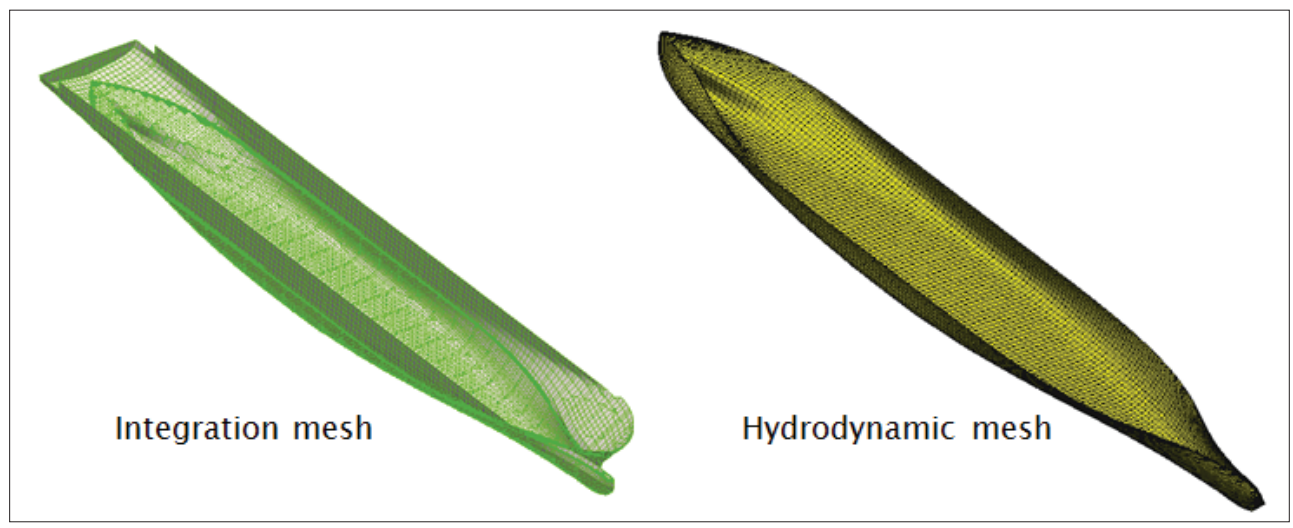

Fig. 4. Integration and hydrodynamic meshes.

SI. 4. Integracijska i hidrodinamička mreža. 
from the structural model, and then the latter one, having 5984 wetted panels on hull, is generated automatically using the existing software routines.

\section{VERIFICATION OF CALCULATION MODELS}

Hydroelastic analysis based on the modal approach requires dry natural vibration analysis as a first step, and in this case 10 global natural modes are retained for the calculation. Before the hydroelastic analysis, it is required to perform some checks to ensure correct numerical setup, proper interactions between used models and their proper positions in the global coordinate system. Therefore, one should:

- verify that calculated still water bending moments and shear forces reasonably agree with those listed in loading manual,

- check still water pressures on ship hull,

- check position of structural model, integration mesh and hydrodynamic mesh relative to free surface,

- verify positions of local models to which top-down is applied along the ship global FE model on elastic modes,

- check still water deflections and stresses both for global FE model and fine mesh models,

- define slamming sections for whipping simulation.

Here only some representative figures are selected. Still water bending moment and shear forces are compared in Figure 5, where very good agreement between HOMER numerical results and loading manual data is achieved. 


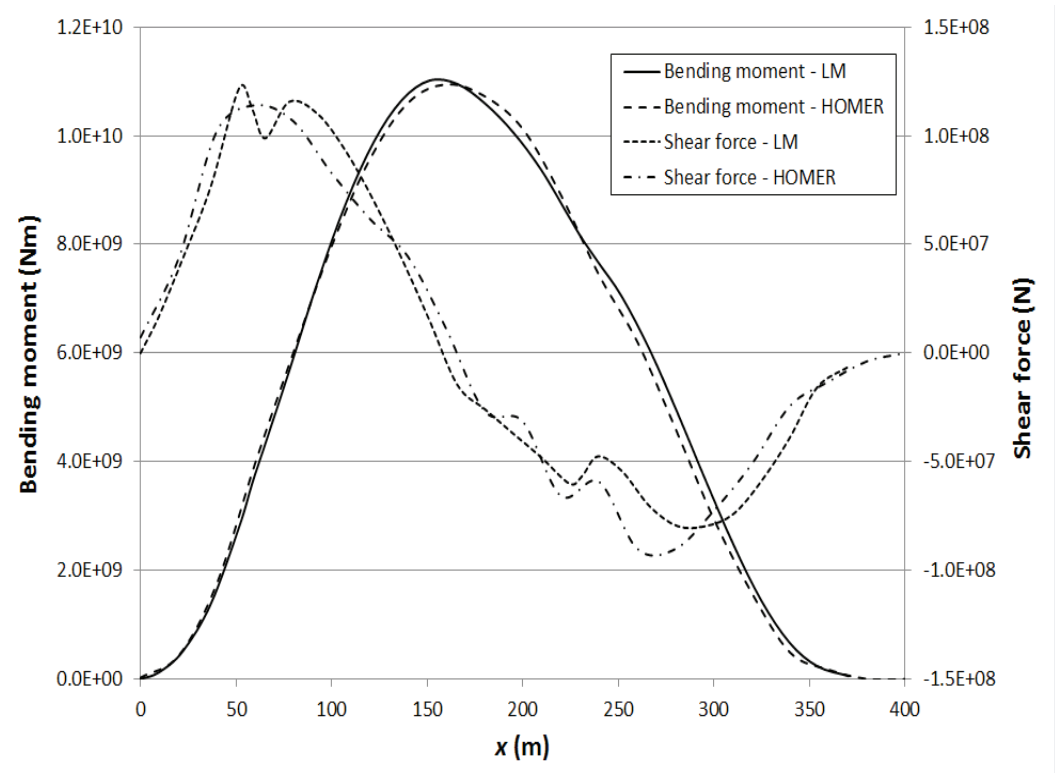

Fig. 5. Still water bending moment and shear force distribution.

Sl. 5. Raspodjela momenta savijanja i smične sile na mirnoj vodi.

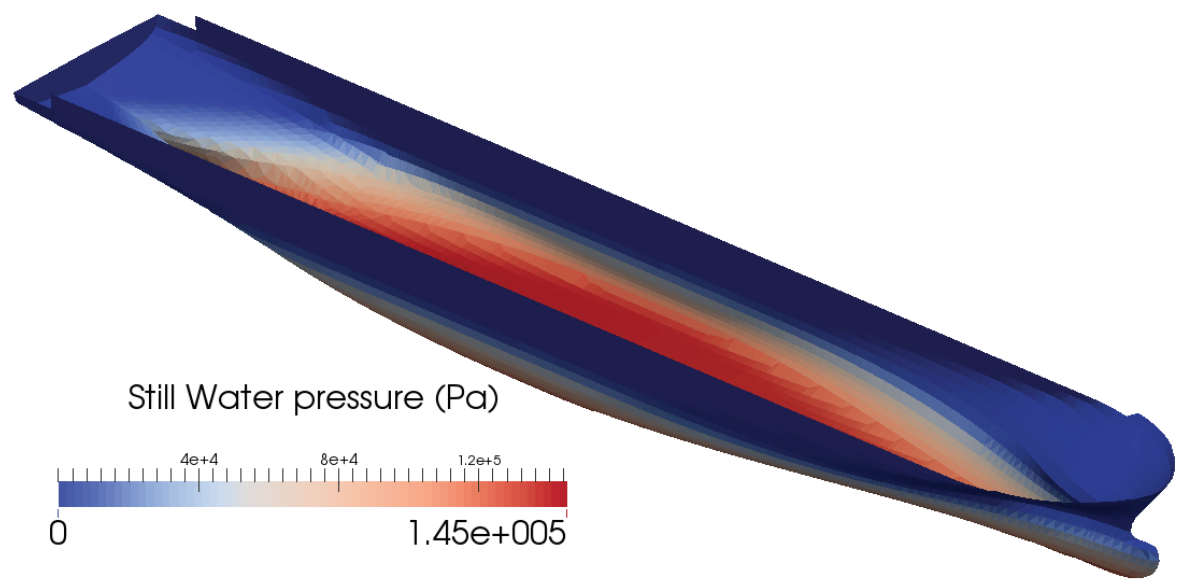

Fig. 6. Distribution of hydrostatic pressure on ship hull.

SI. 6. Raspodjela hidrostatičkog tlaka na brodskom trupu. 
Realistic values of still water pressure on ship hull, as well as appropriate positioning of structural and integration meshes is evident from Figures 6, 7, and 8, respectively.

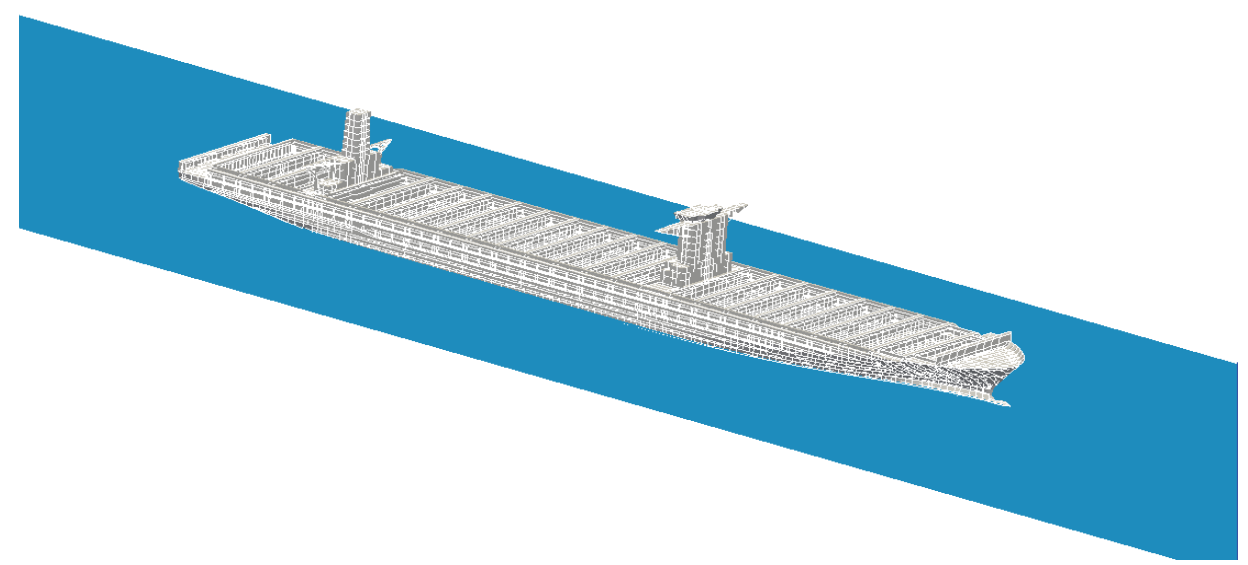

Fig. 7. Position of structural model relative to free surface.

SI. 7. Položaj strukturnog modela u odnosu na slobodnu površinu.

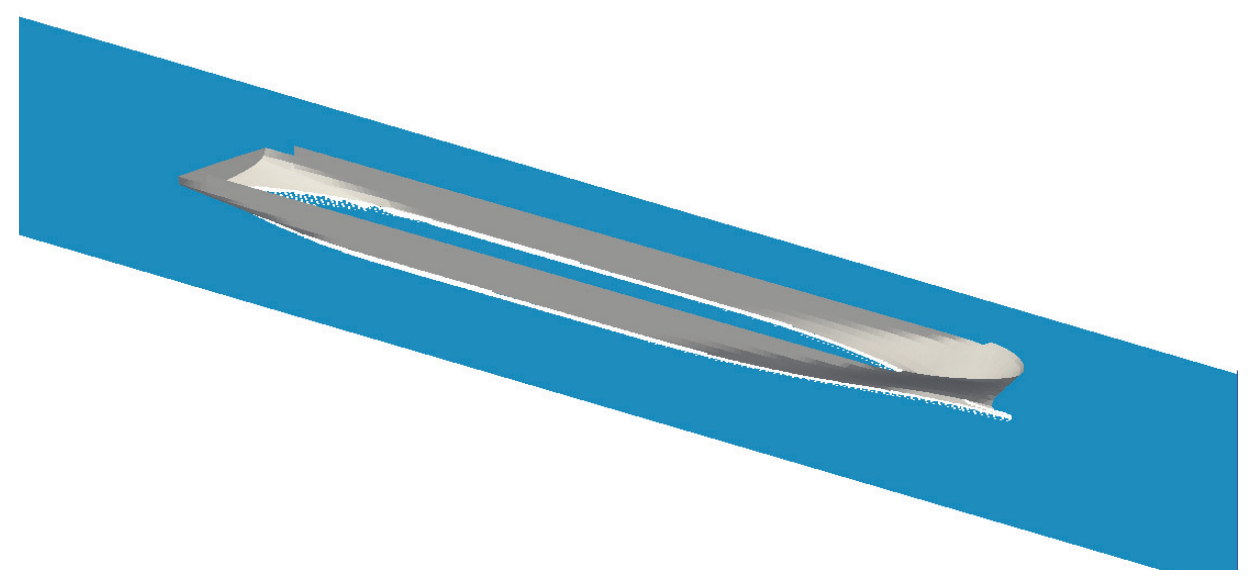

Fig. 8. Position of integration mesh relative to free surface.

SI. 8. Položaj integracijske mreže u odnosu na slobodnu površinu.

Positions of fine mesh models along the deformed structural finite element model are presented for elastic modes in Figure 9. Figures 10 and 11 show still water von Mises stresses of the ship and details 11-14, respectively.

In total 8 slamming sections are created along the front quarter of the ship to perform whipping simulations, Figure 12. 
Fig. 9. Wireframe presentation of dry natural modes of container ship with fine mesh models for top-down procedure.

SI. 9. Prikaz suhih prirodnih oblika vibriranja kontejnerskog broda s modelima usitnjene mreže.

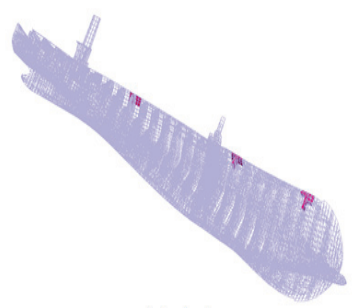

Mode 1

$\omega_{1, \text { ary }}=1.86 \mathrm{rad} / \mathrm{s}$

$\omega 1$, wet $=1.72 \mathrm{rad} / \mathrm{s}$

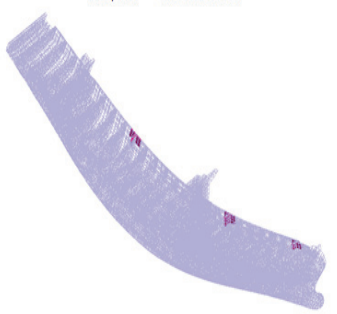

Mode 3

$\omega 3, d r y=3.61 \mathrm{rad} / \mathrm{s}$

$\omega 3$, wet $=2.70 \mathrm{rad} / \mathrm{s}$

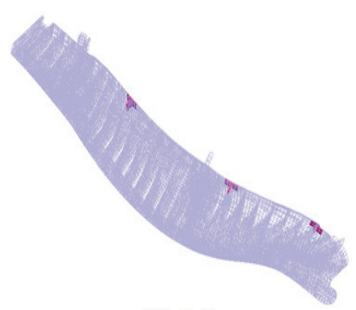

Mode 2 $\omega 2, d r y=2.68 \mathrm{rad} / \mathrm{s}$ $\omega 2$, wet $=2.49 \mathrm{rad} / \mathrm{s}$

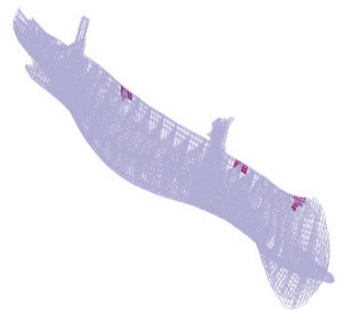

Mode 4

$(\omega 4, d r y=5.07 \mathrm{rad} / \mathrm{s}$ $\omega 4$, wet $=4.80 \mathrm{rad} / \mathrm{s}$

Fig. 10. Presentation of still water von Mises stresses (Pa) on deformed model in hogging condition.

SI. 10. Prikaz von Mises naprezanja (Pa) na mirnoj vodi na deformiranom modelu u stanju pregiba. 


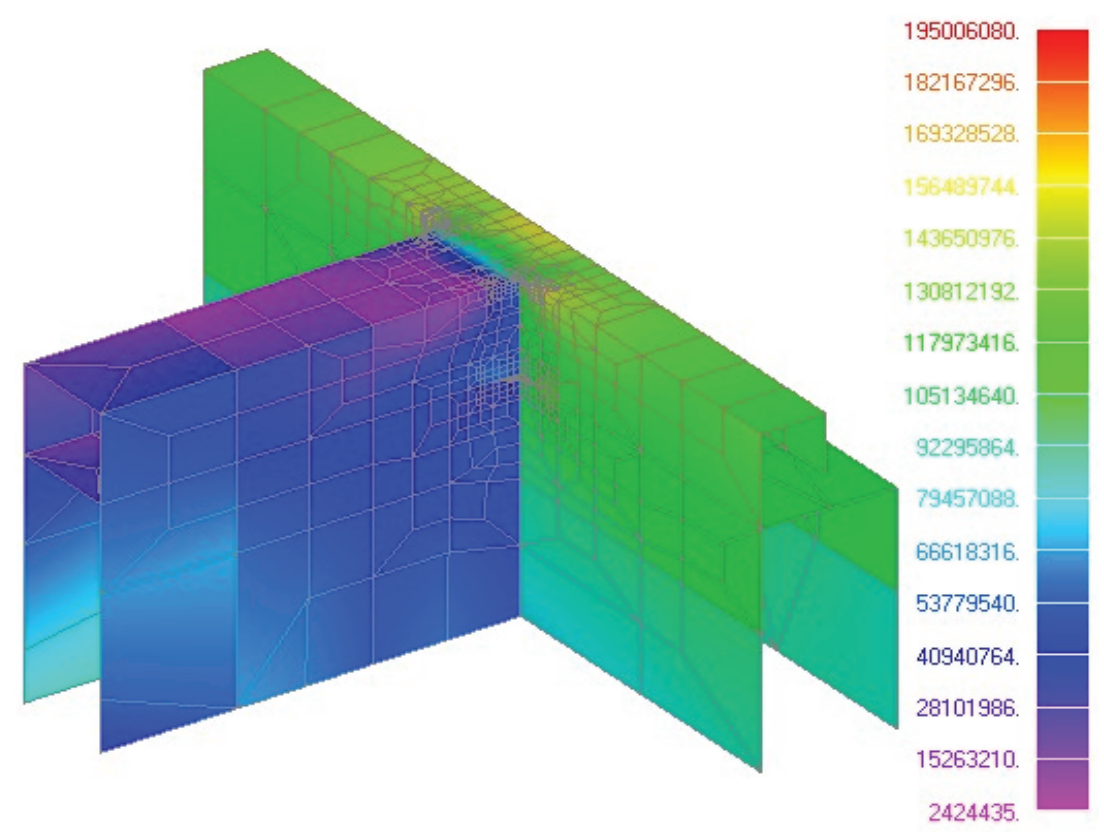

Fig. 11. Still water von Mises stresses in details 11-14 (Pa).

SI. 11. Von Mises naprezanja (Pa) na mirnoj vodi za detalje 11-14.

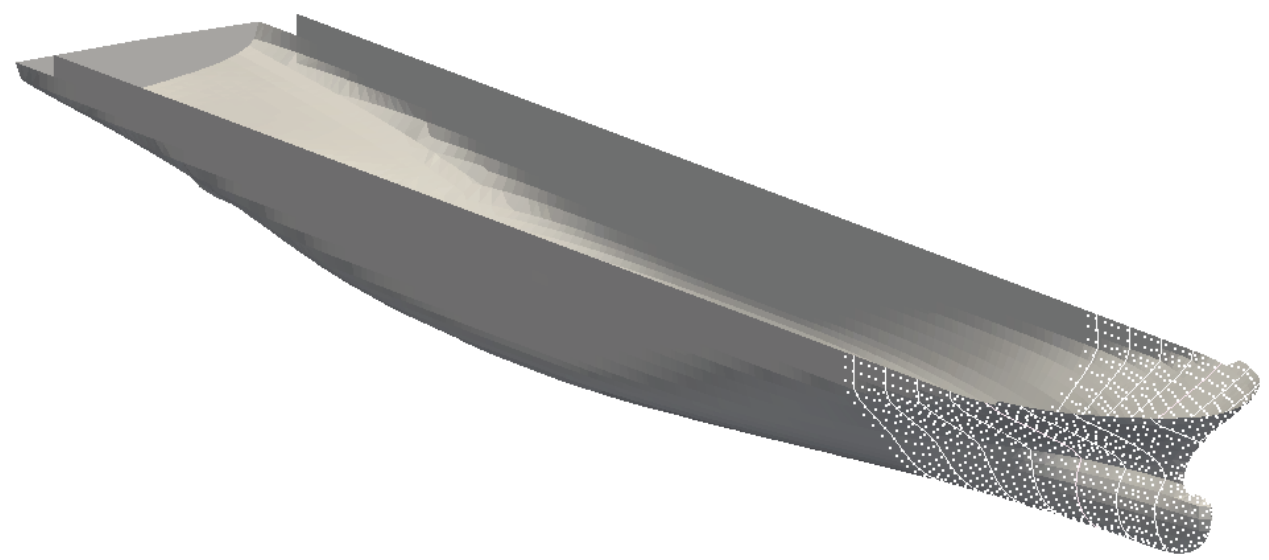

Fig. 12. Definition of slamming sections for whipping simulations.

Sl. 12. Definicija odsječaka za proračun udaranja pramca o valove i simulaciju podrhtavanja brodskog trupa. 


\section{RESULTS}

\subsection{Global hydroelastic response}

Global ship hydroelastic response, i.e. RAOs (Response Amplitude Operators) of vertical bending moments at midship for heading angles $\beta=130^{\circ}$ and $180^{\circ}$, are presented in Figure 13, while RAOs of torsional moments at $0.25 \mathrm{~L}$ and $0.75 \mathrm{~L}$ are shown in Figure 14.

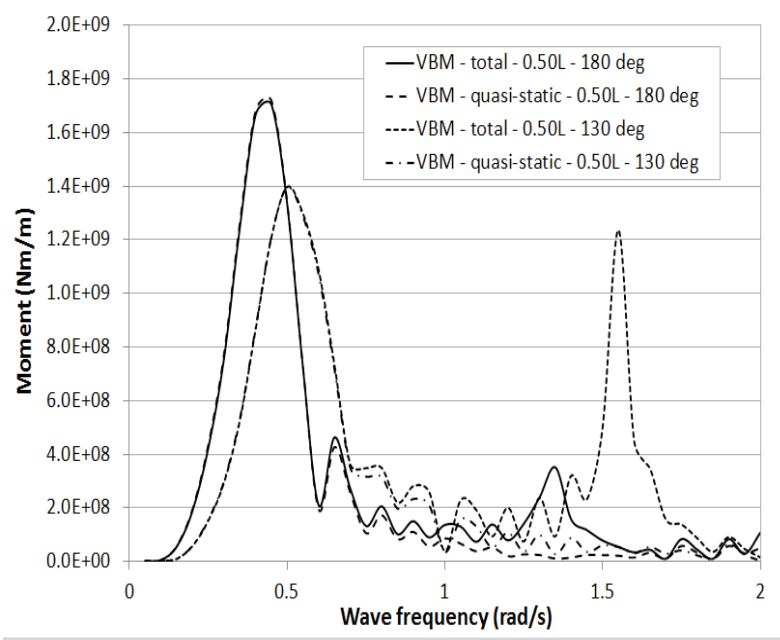

Fig. 13. RAOs of vertical bending moments at midship.

SI. 13. Prijenosne funkcije vertikalnih momenata savijanja na sredini broda.

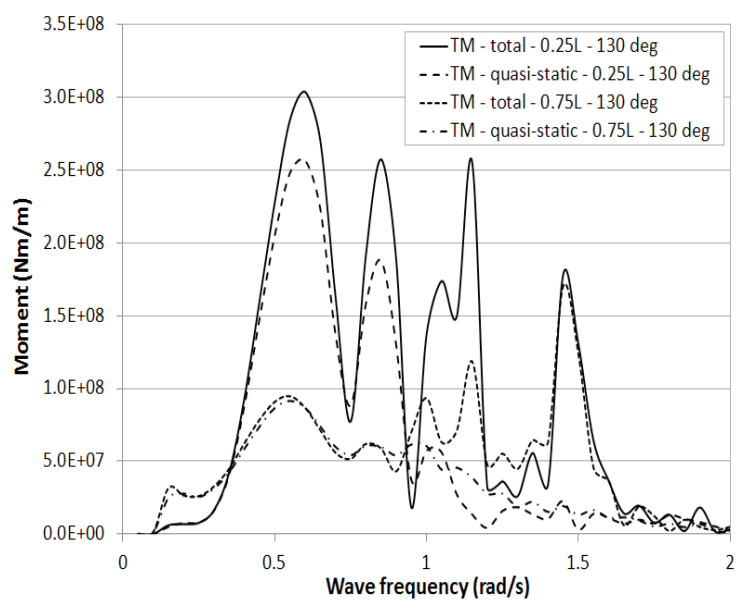

Fig. 14. RAOs of torsional moments.

SI. 14. Prijenosne funkcije momenata uvijanja. 


\subsection{Local response - stress RAOs}

Similarly as in the case of sectional moments, obtained representative stresses for fatigue computation are also presented as the rigid body component and total quantity, Figures 15 and 16.

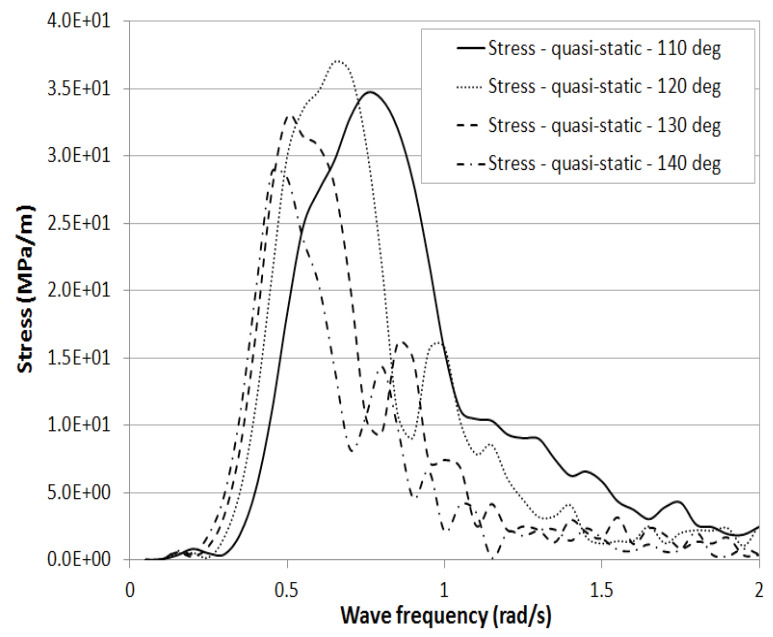

Fig. 15. Quasi-static stress RAOs, detail 13.

SI. 15. Prijenosne funkcije kvazi-statičke komponente naprezanja, detalj 13.

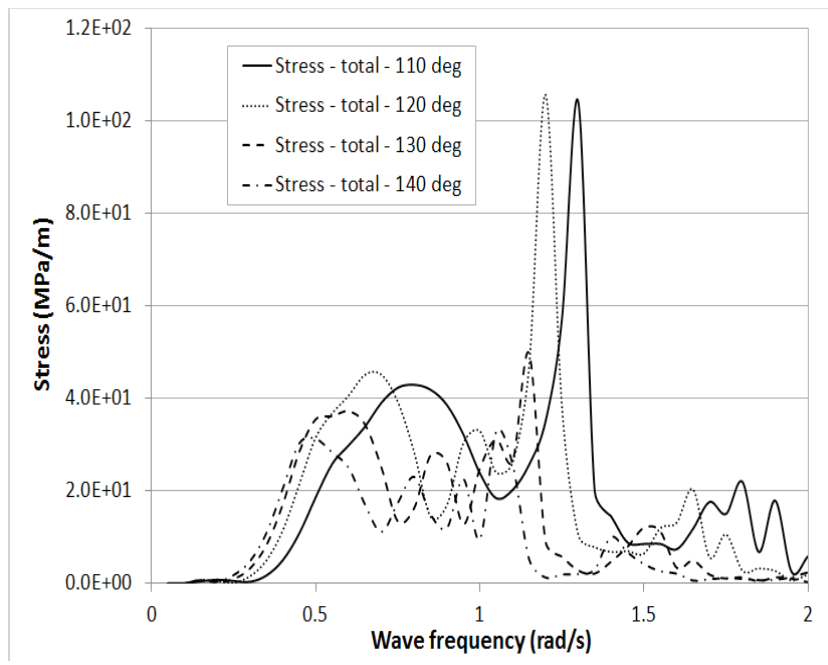

Fig. 16. Total stress RAOs, detail 13.

SI. 16. Prijenosne funkcije ukupnog naprezanja, detalj 13. 


\subsection{Whisp1 - fatigue strength check}

Stress RAOs are used as input for fatigue calculation. The axial stress in the rod elements at the free edges of hatch corners of fine mesh FE models is taken into account. Fatigue lives of selected structural details are presented in Table 2. The results are obtained for sailing factor equal to 0.85 and mean stress effect is taken into account.

Table 2. Fatigue lives of analyzed structural details

Tablica 2. Dinamička izdržljivost analiziranih konstrukcijskih detalja

\begin{tabular}{|c|c|c|c|c|c|}
\hline \multirow{2}{*}{ Position } & \multicolumn{2}{|c|}{ Fatigue life (years) } & \multirow{2}{*}{ Position } & \multicolumn{2}{c|}{$\begin{array}{c}\text { Fatigue life (years) } \\
\text { Quasi-static }\end{array}$} \\
\cline { 5 - 6 } Quasi-static & Total & & 8 & 468.2 & 367.9 \\
\hline 1 & 52329411 & 11144705 & 9 & 380.6 & 161.1 \\
\hline 2 & 379764 & 106494 & 10 & 3576.5 & 529.8 \\
\hline 3 & 8367058 & 6382352 & 11 & 172.0 & 98.4 \\
\hline 4 & 2082 & 579.6 & 12 & 656.9 & 208.1 \\
\hline 5 & 1216470 & 276470 & 13 & 102.7 & 40.2 \\
\hline 6 & 1073 & 309.8 & 14 & 206.9 & 73.9 \\
\hline 7 & 179.8 & 124.1 & & & \\
\hline
\end{tabular}

Minimum fatigue life is obtained for detail 13 and yields 40.2 years. Therefore, it can be concluded that all analysed details satisfy WhiSp1 criterion (28 years if WhiSp3 is not granted and 25 years if WhiSp3 is granted as stated in [9]).

\subsection{WhiSp2 - ultimate strength check}

A spectral analysis is performed considering the IACS recommendations with VMB $\mathrm{RAO}$ as a loading parameter. The contributions from all the sea states show that the highest contribution to VBM is given by a head sea state, Figure 17, with the following wave period and wave height: $T_{p}=16.19 \mathrm{~s}, H_{s}=14.50 \mathrm{~m}$. In order to improve the convergence (to reduce simulation duration), the concept of so called increased design sea state (IDSS) is applied, Figure 18. It means that the wave height is increased to reduce return period of VBM. Therefore, parameters for whipping simulation are set at $T_{p}=16.19 \mathrm{~s}$ and $H_{s}=17.12 \mathrm{~m}$. Simulation time is determined based on the 25-years extreme VBM on IDSS (1097 s) and yields $22000 \mathrm{~s}$ (nearly 20 times higher). Typical VBM time histories, taking into account ship flexibility and slamming induced whipping are shown in Figure 19 where the linear VBM is also presented for comparison.

Postprocessing of time signal is done to obtain extreme long term values of total bending moments, that yield $2.743 \cdot 10^{10} \mathrm{Nm}$ (hogging) and $-2.187 \cdot 10^{10} \mathrm{Nm}$ (sagging). Ge- 


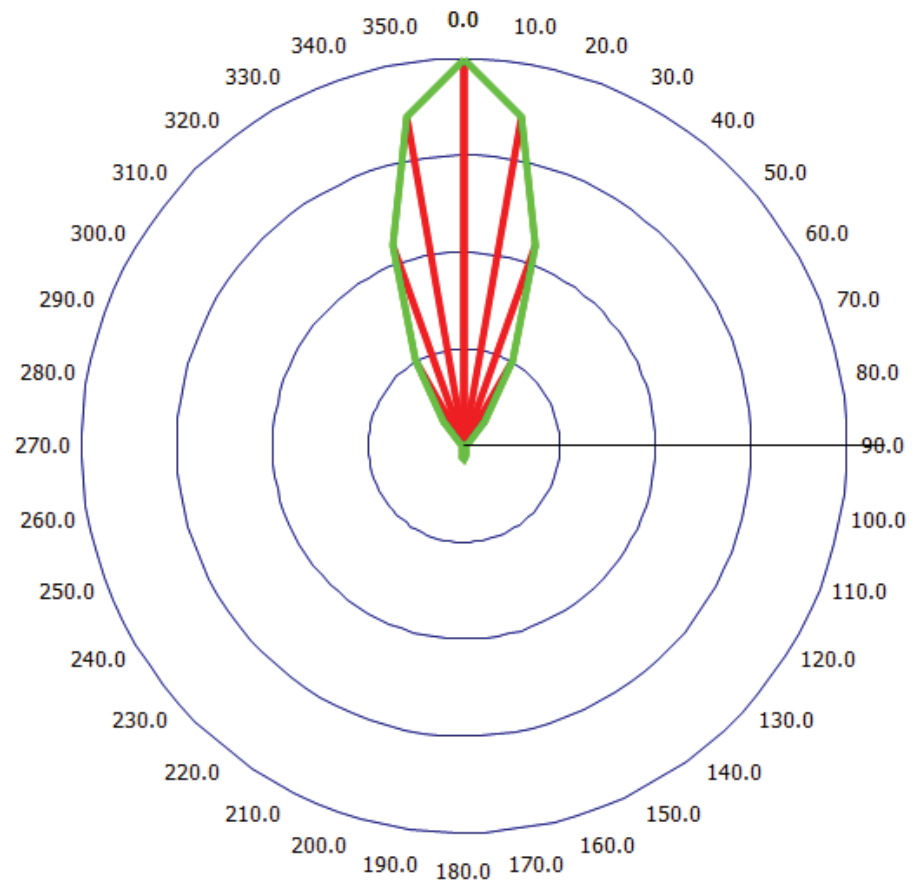

Fig. 17. Azimuth contribution to VBM.

SI. 17. Ovisnost vertikalnog momenta savijanja o susretnom kutu broda i valova.

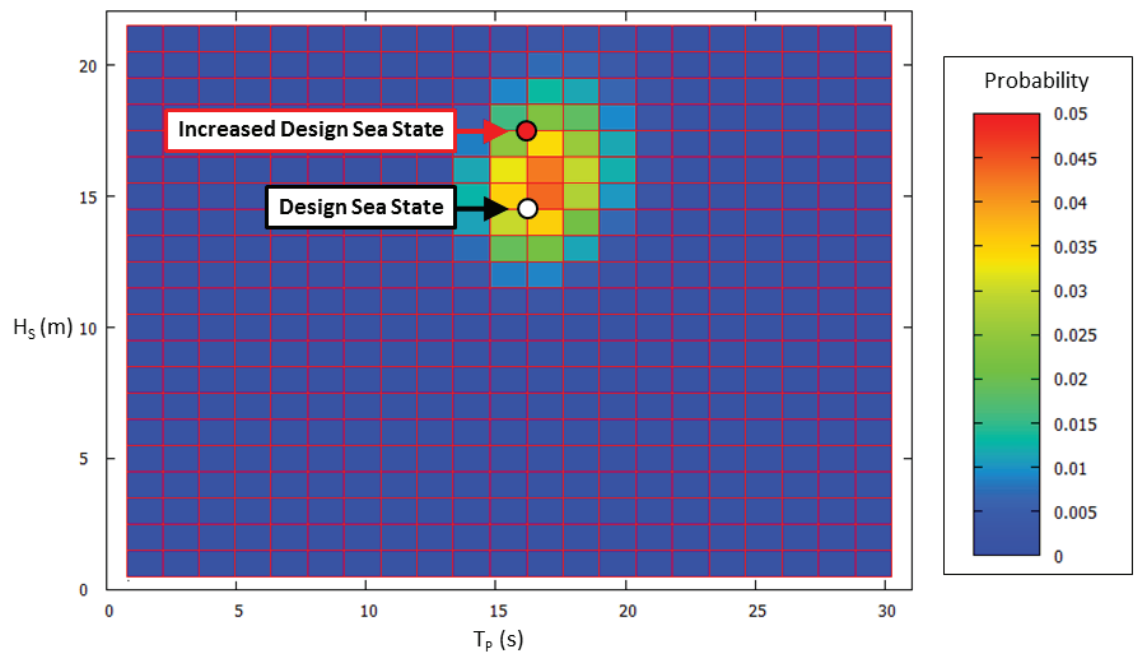

Fig. 18. Increased design sea state concept.

SI. 18. Koncept povišenog projektnog stanja mora 


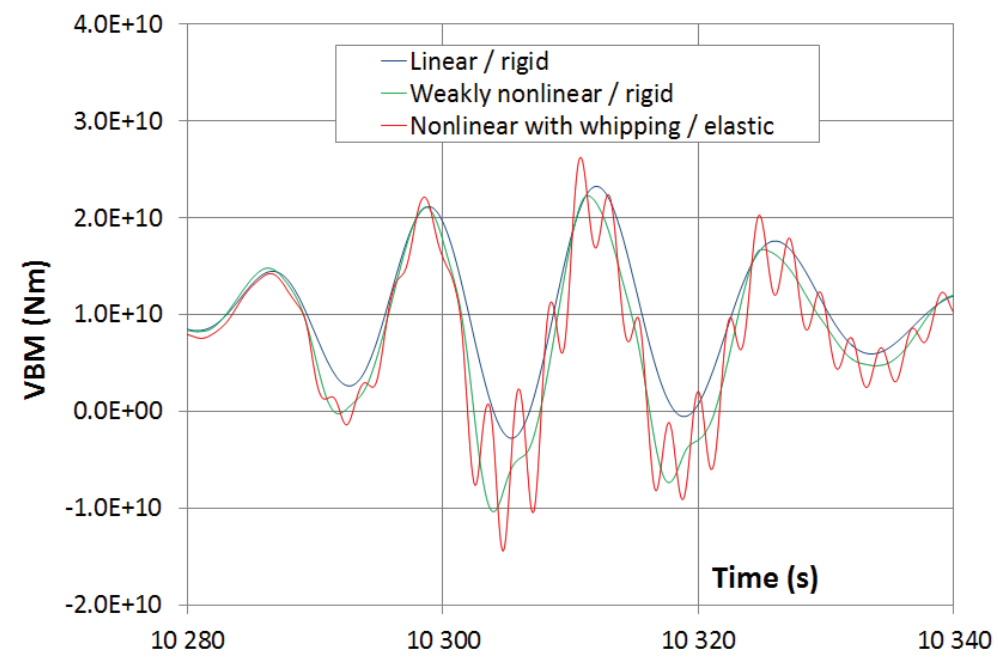

Fig. 19. Typical VBM time history at midship section of container ship [7].

SI. 19. Tipični vremenski zapis vertikalnog momenta savijanja na sredini kontejnerskog broda [7].

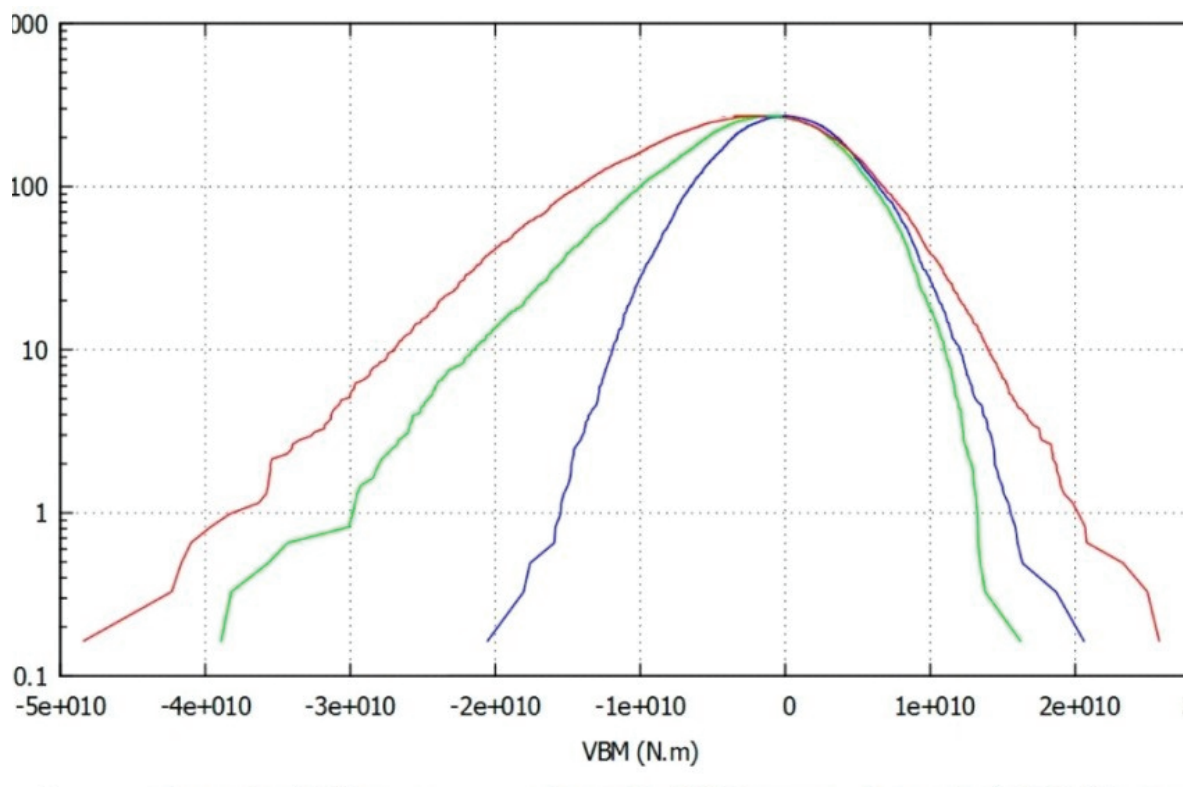

Conventional_UN

Fig. 20. VBM up-crossing extrema distribution for container ship at midship [7].

SI. 20. Distribucija ekstremnih vertikalnih momenata savijanja kontejnerskog broda [7]. 


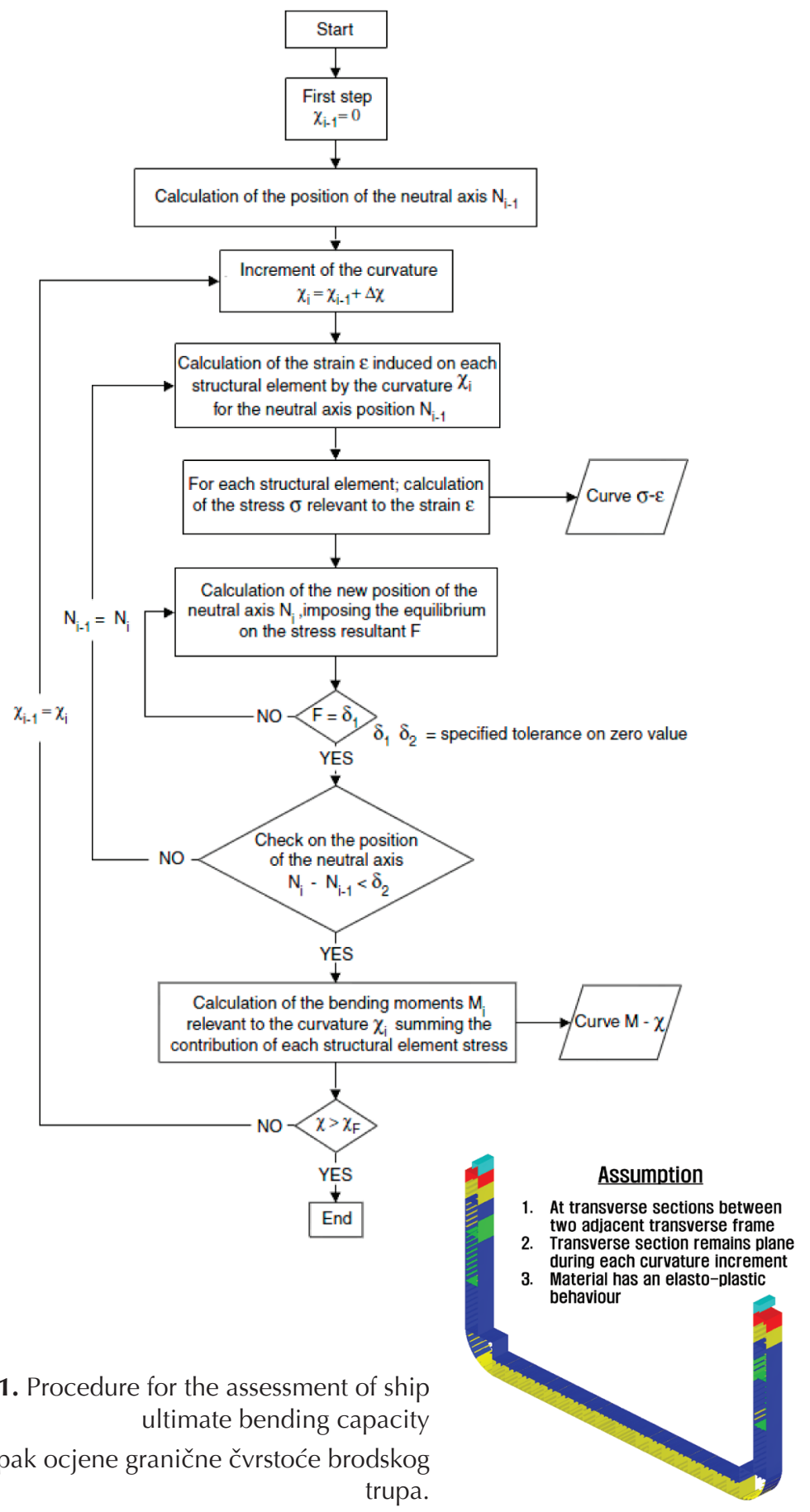


nerally, one can see that the maximum bending moment is significantly increased due to whipping, Figure 20.

Ultimate bending capacity of the hull girder is determined by non-linear FE analysis using Abaqus, [15], according to the flowchart given in Figure 21.

According to the results presented in Figure 22, ultimate bending capacity of a ship hull yields 3.918 $10^{10} \mathrm{Nm}$. By introducing relevant quantities into Eq. (5), one obtains:

$$
\begin{aligned}
& 2.743 \cdot 10^{10} \leq \frac{3.918 \cdot 10^{10}}{1.1} \\
& 2.743 \cdot 10^{10} \leq 3.562 \cdot 10^{10}
\end{aligned}
$$

Since the obtained quantities satisfy Eq. (5), one can confirm that the analyzed container ship fits to WhiSp2 criteria.

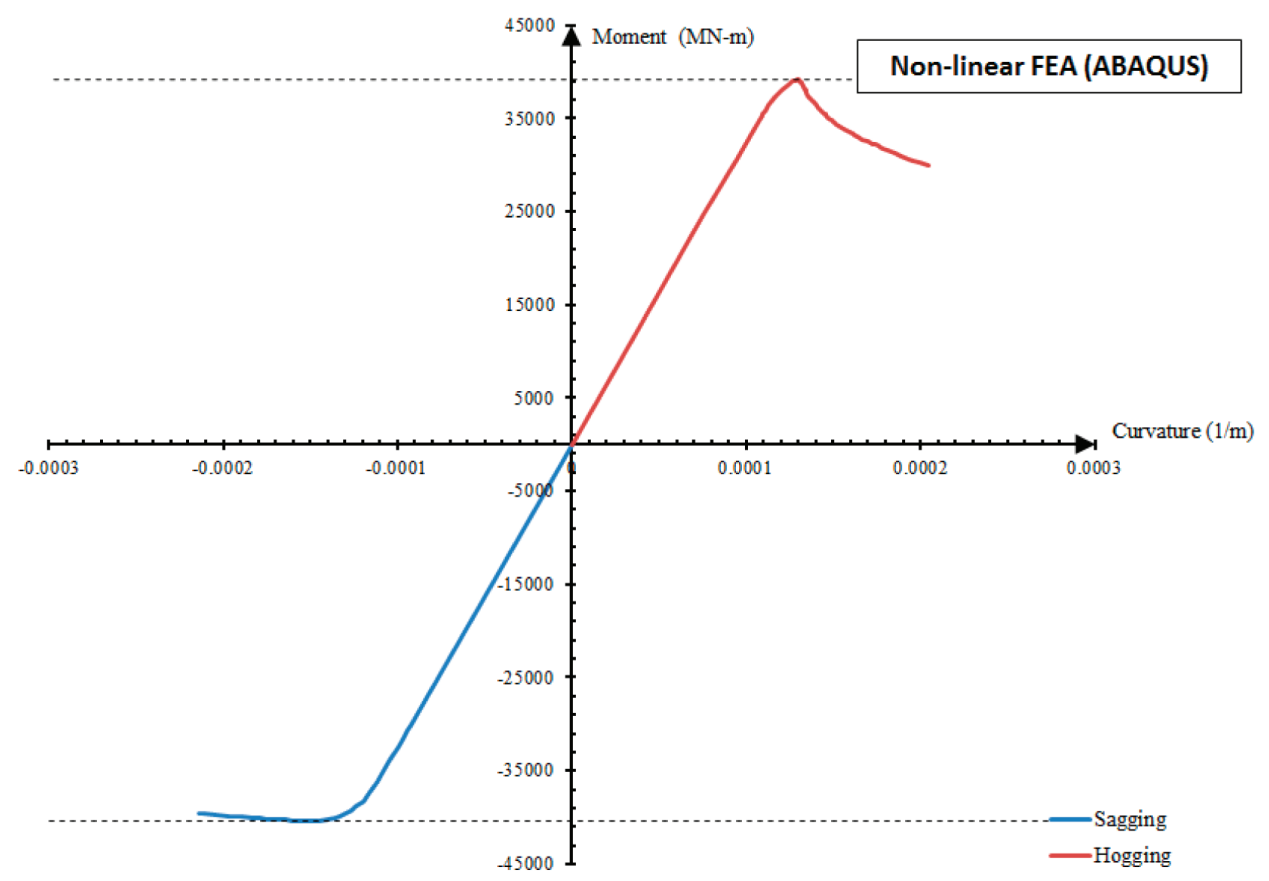

Fig. 22. Moment vs. curvature curve for container ship midship section

SI. 22. Krivulja moment savijanja-zakrivljenost za središnji poprečni presjek kontejnerskog broda. 


\section{CONCLUSION}

A procedure for ship direct strength evaluation is illustrated in the case of an ultra large container ship example. It is done according to the new guidelines issued by $\mathrm{Bu}-$ reau Veritas Classification Society. Hydro-structural tool HOWER was applied. The modal approach is employed for determination of global ship hydroelastic response, and top-down procedure is applied to determine stress concentrations using the fine mesh models of selected structural details. The results indicate that no fatigue cracks are expected before 40.2 years, which implies that WhiSpl criterion is satisfied. The computed long term VBM is compared with structure ultimate bending capacity determined by non-linear FEM results, and it is found that the ship can withstand imposed load, i.e. WhiSp2 criterion is also satisfied. Both findings are in line with the fact that the analysed ship was built several years ago, and safely operates worldwide, without any fatigue damage registered for the time being. It is necessary to mention that described procedure and used numerical tools for direct strength assessment of ship structures can be applied to any ship type and size.

\section{Acknowledgements}

This work was presented at the Annual Spring Meeting of The Society of Naval Architects of Korea (SNAK), organized by the Korean Association of Ocean Science and Technology Societies (KAOSTS), Busan (BEXCO), Korea, in May 2016. Also, some contributions are presented in earlier papers of the authors, which are properly cited within the manuscript and included in the reference list. The investigations have been done within the Joint Research Project (JRP) "A Study on Springing and Whipping of Hyundai SkyBench ${ }^{\mathrm{TM}}$ Container Carrier". Authors are grateful to Quentin Derbanne and Maximilien Basquin from Bureau Veritas, Paris, for valuable discussions related to WhiSp methodology application. Also, the support of the Korean Government (MSIP) and National Research Foundation of Korea (NRF) through GCRC-SOP (Grant No. 2011-0030013) is greatly acknowledged.

\section{References}

[1] Malenica, Š, Vladimir, N, Senjanović, I. Proceedings of the $2^{\text {nd }}$ International Workshop on Springing and Whipping of Ships, Vidici, Velika Rakovica, Samobor, Croatia, 2012, 195 pages.

[2] Malenica, Š, Derbanne, Q, Sireta, FX, Bigot, F, Tiphine, E, De Hauteclocque, G, Chen, XB. "HOMER - Integrated hydro-structure interactions tool for naval and offshore applications," Int Conf on Computers Applications in Shipbuilding, Busan, Korea, 2013.

[3] Malenica, Š, Senjanović, I, Vladimir, N. "Hydro structural issues in the design of ultra large container ships," Brodogradnja, 64(3), 2013, 323-347. 
[4] Senjanović, I, Vladimir, N, Tomić, M, Hadžić, N, Malenica, Š. "Global hydroelastic analysis of ultra large container ships by improved beam structural model," Int J Nav Arch and Ocean Eng, 6(4), 2014, 1041-1063.

[5] Senjanović, I, Vladimir, N, Tomić, M, Hadžić, N, Malenica, Š. "Some aspects of structural modelling and restoring stiffness in hydroelastic analysis of large container ships," Ships and Offshore Struct, 9(2), 2014, 199-217.

[6] Im, H. I, Vladimir, N, Malenica, Š, Cho, DS. "Quasi-static response of 19,000 TEU class ultra large container ship with novel mobile deckhouse for maximizing cargo capacity," Trans of FAMENA, 2017, (accepted for publication).

[7] Im, H. I, Vladimir, N, Malenica, Š, Cho, DS. "Hydroelastic response of 19,000 TEU class ultra large container ship with novel mobile deckhouse for maximizing cargo capacity," Int J Nav Arch Ocean Eng, 2017, http://dx.doi.org/10.1016/j.ijnaoe. 2016.11.004.

[8] Vladimir, N, Malenica, Š, De Lauzon, J, Senjanović, I, Im, H. I, Choi, B. K, Cho, D. S. "Structural design of ultra large ships based on direct calculation approach," Pomorski zbornik / J Marit Transp Sci, Special Issue (1), 2016, 63-79.

[9] Bureau Veritas. Whipping and Springing Assessment, Rule Note NR 583 DT R00 E. Paris, France, 2015.

[10] Bureau Veritas. Hydrostar, User's manual. Paris, France, 2006.

[11] MSC Software. MD "NASTRAN" 2010 Dynamic analysis user's guide. Newport Beach, California, USA, 2010.

[12] Sireta, F. X, Derbanne, Q, Bigot, F, Malenica, Š, Baudin, E. "Hydroelastic response of a ship structural detail to seakeeping loads using a top-down scheme," Proc Int Conf on Ocean, Offshore and Arctic Eng - OMAE, ASME, Rio de Janeiro, Brasil, 2012.

[13] Bishop, R. E. D, Price, G. Hydroelasticity of Ships, Cambridge University Press, 1979.

[14] Sireta, F. X, De Lauzon, J, Surmont, F. HOMER User guide. Paris, France, 2013.

[15] Dassault Systémes. "ABAQUS" analysis user's manual. Version 6.8. Providence, RI, USA: Dassault Systémes, 2008. 


\title{
OCJENA SIGURNOSTI KONSTRUKCIJE VELIKOG KONTEJNERSKOG BRODA
}

\author{
Sažetak
}

Trend u suvremenom pomorskom prometu je gradnja sve većih kontejnerskih brodova, koji zahtijevaju primjenu različitih programskih paketa u skladu s odgovarajućim metodologijama, da bi se postigla odgovarajuća sigurnost njihove konstrukcije. Cilj ovog rada je prikaz direktnog postupka za analizu čvrstoće broda na temelju dugoročnih hidro-strukturnih proračuna, uključujući utjecaj pruženja i podrhtavanja trupa. Kao ilustrativni primjer, odabran je veliki kontejnerski brod nosivosti 19000 kontejnera, te je izvršena ocjena sigurnosti njegove konstrukcije prema kriteriju zamora i ekstremnih opterećenja. Matematički model se temelji na sprezanju 3D potencijalnog hidrodinamičkog modela i 3D strukturnog modela konačnih elemenata. Korišten je opći programski paket za hidroelastičnu analizu HOMER, razvijen u klasifikacijskom društvu Bureau Veritas (BV). Za odabrane detalje konstrukcije izračunate su prijenosne funkcije naprezanja na temelju tzv. top-down postupka, te je izračunat njihov zamorni vijek. Linearna dugoročna analiza s vertikalnim momentnom savijanja kao parametrom opterećenja je provedena za definiranje reprezentativnih stanja mora. Podrhtavanje broda je određeno za tzv. povišeno stanje mora, u vremenskoj domeni. Naposljetku, određen je ekstremni vertikalni moment savijanja, i provjerena je granična čvrstoća konstrukcije prema BV Rule Note NR583.

Ključne riječi: kontejnerski brod; direktni proračun; hidroelastičnost; zamor; ekstremni odziv; frekvencijska domena; vremenska domena.

\author{
Nikola Vladimir \\ University of Zagreb \\ Faculty of Mechanical Engineering \\ and Naval Architecture \\ Ivana Lučića 5, 10000 Zagreb \\ Croatia \\ e-mail: nikola.vladimir@fsb.hr
}

\section{Ivo Senjanović}

University of Zagreb

Faculty of Mechanical Engineering

and Naval Architecture

Ivana Lučića 5, 10000 Zagreb

Croatia

e-mail: ivo.senjanovic@fsb.hr

\section{Hong-II Im}

Hyundai Heavy Industries Co., Ltd.

1000, Bangeojinsunhwan-doro

Dong-gu, Ulsan

South Korea

e-mail: okil@hhi.co.kr

\section{Šime Malenica}

Bureau Veritas

Research Department

67/71, Boulevard du Château

92571 Neuilly - Sur - Seine Cdx

France

e-mail: sime.malenica@bureauveritas.com

Jérôme De Lauzon

Bureau Veritas

Research Department

67/71, Boulevard du Château

92571 Neuilly - Sur - Seine Cdx

France

e-mail: jerome.de-lauzon@bureauveritas.com

\section{Dae-Seung Cho}

Pusan National University

63 beon-gil 2, Busandaehak-ro, Geumjeong-gu

Busan, 46239

South Korea

email: daecho@pusan.ac.kr 